Sari Karttunen ja Marjo Mäenpää

\title{
KORONAKRIISI KÄRJISTÄÄ \\ KULTTUURITALOUDEN RAKENTEELLISTA \\ EPÄVAKAUTTA JA EPÄTASA-ARVOA
}

\author{
The corona crisis exacerbates the structural instability and \\ inequality of the cultural economy
}

\begin{abstract}
The authors participate in the European Commission's Open Method of Coordination Expert Group on Gender Equality in the Creative and Cultural Sectors (CCS) (20192021), where they are tasked with reflecting on the gender impact of the Covid pandemic in the CCS labour market. Little information is available on the subject, as demographic background has been asked in only a few Covid surveys. In general, the pandemic is seen as exacerbating the situation of the vulnerable groups in the labour market and threatening to reverse the development of gender equality. The CCS has been hit hard by the pandemic, especially artistic and cultural forms that require physical presence, such as performing arts and festivals. In the CCS workforce, there are more self-employed and atypical workers than average. CCS workers seldom have buffer savings, and their social security may be deficient. Cultural analysts have estimated that the sector will lose in workforce because of the pandemic, and its diversity is in danger of shrinking as the most disadvantaged groups are forced to leave. Public policy measures are needed to address this development as soon as possible. The current crisis should not be dealt with as a temporary phenomenon, but the fundamental structural problems of the cultural economy need to be tackled.
\end{abstract}

Key words: Covid-19, crisis, cultural economy, instability, inequality, gender, change

Artikkeli liittyy kirjoittajien työskentelyyn Euroopan komission avoimen koordinaation työryhmässä "Gender equality in the cultural and creative sectors" vuosina 2019-2020. Kirjoittajien toimeksianto on pohtia loppuraporttiin koronapandemian mahdollisia sukupuolisidonnaisia vaikutuksia kulttuurialalla.

Kansainvälisten arvioiden mukaan koronapandemian vaikutukset työmarkkinoihin ovat merkittäviä ja kohdistuvat vallitsevan sukupuolijärjestelmän takia epäsuhtaisesti naisiin ja miehiin ${ }^{1}$. Koronan aiheuttamat töiden ja tulojen menetykset ovat suuria naisvaltaisilla aloilla, kuten hotelli- ja ravintola-alalla. Terveydenhuollossa naiset ovat pitäneet työpaikkansa mutta altistuneet terveysriskeille. Miehet sijoittuvat naisia useammin tehtäviin, joissa etätyöskentely on mahdollista. Naisille etätyö on vaativampaa, koska he kantavat suuremman vastuun kotitöistä ja lastenhoidosta. Korona-aikana kotona on myös ollut lapsia etäopetuksessa, ja erityisen tiukkaa on ollut yksinhuoltajavanhemmilla, joista suurin osa on naisia. (Ks. esim. Alon, Doepke, Olmstead-Rumsey \& Tertilt, 2020; United Nations, 2020; World Bank, 2020.)

Pandemian on ennustettu johtavan taantumaan EU:n alueella ja pahentavan työmarkkinoilla vallitsevaa rakenteellista epätasa-arvoa. Euroopan tasa-arvoinstituutti EIGE muistuttaa, että tilapäisissä ja epätyypillisissä työsuhteissa työskentelevät ovat taloudellisesti erityisen haa- 
voittuvia (EIGE, 2020). Naisilla osa-aikainen ja epäsäännöllinen työ on yleisempää kuin miehillä, ja heidän työsuhteensa ovat useammin pätkittäisiä ja määräaikaisia. Heikko-osaisuutta lisäävät risteävää epätasa-arvoa aiheuttavat tekijät, kuten vammaisuus, alhainen sosioekonominen asema, maahanmuuttajatausta ja hoivavelvollisuudet.

Luovilla ja kulttuurialoilla ${ }^{2}$ pandemia on paljastanut rakenteellisen haurauden ja kyvyttömyyden suojautua taloudellisilta iskuilta (ks. esim. Banks, 2020; Comunian \& England, 2020; Eikhof, 2020). Tsioulakis ja FitzGibbon (2020) huomauttavat, että viimeisten kahden vuosikymmenen aikana työskentelyedellytykset alalla ovat monissa maissa heikentyneet globaalien ja kotimaisten talouskriisien vuoksi. Comunian ja England (2020) toteavat termien prekaari ja prekaarius ilmestyneen kulttuurialojen työvoimaa koskeviin tutkimuksiin ja keskusteluihin vuoden 2008 finanssikriisin jälkimainingeissa.

Kulttuuritaloutta kuvataan usein poikkeukselliseksi (Bourdieu, 1993) ja jopa julmaksi (Abbing, 2002). Caves (2000) nimeää seitsemän periaatetta, jotka luonnehtivat luovien alojen taloudellista organisoitumista ja toimintalogiikkaa. Näistä periaatteista esimerkiksi "kukaan ei tiedä” viittaa kysynnän epävarmuuteen: kuluttajien reaktioita kulttuurituotteeseen ei useinkaan osata ennustaa, eikä niiden selittäminen jälkikäteenkään aina onnistu. Epävarmuus johtaa tuotteiden ja tuottajien ylitarjontaan. "Taide taiteen vuoksi" puolestaan tarkoittaa, että alan toimijat arvostavat työnsä sisältöä ja tavoitteita niin paljon, että ovat valmiita tinkimään toimeentulostaan. (Caves, 2000.) Normaaleinakin aikoina monet taiteilijoista elävät taloudellisessa epävarmuudessa, jopa köyhyydessä. Luovan sektorin työntekijöillä on keskimäärin vähemmän tuloja ja puskurisäästöjä kuin muilla aloilla toimivilla ihmisillä, joilla on vastaava määrä koulutusta ja työkokemusta.

Pandemian ja sen edellyttämien sulkutoimien vaikutukset kulttuurialan ammattitoimintaan ovat olleet merkittäviä. Erityisen vaikeaa on ollut fyysiseen läsnäoloon perustuvilla taiteenaloilla, joiden työskentely- ja esitystilat pantiin kiinni ensimmäisinä. Sen sijaan esimerkiksi graafinen suunnittelu tai kirjoittaminen soveltuvat helpommin etätyöhön. Suurista instituutioista kiinteää palkkaa saavat ovat pärjänneet kriisissä paremmin kuin freelancerit (Banks, 2020). Kulttuurialoilla itsensä työllistävien osuus on keskimääräistä suurempi. Keikka- tai projektipohjaisesti työskentelevillä ei useinkaan ole suojaa työtehtävien peruutuksilta, ja epätyypillisten järjestelyjen vuoksi heidän sosiaaliturvassaan on monesti puutteita. Pandemian aikana kulttuurialan työntekijöitä on useassa Euroopan maassa pudonnut yleisten koronatukijärjestelmien ulkopuolelle (ks. esim. Eikhof, 2020; Tsioulakis \& FitzGibbon, 2020).

Pandemian sukupuolivaikutuksista kulttuurialoilla on saatavilla vain vähän tietoa. Comunian ja England (2020) toteavat, että vaikka koronakyselyitä on tehty runsaasti, niissä on harvoin tiedusteltu vastaajan sukupuolta tai muita demografisia taustatietoja. Näitä tietoja tarvittaisiin pandemian vaikutusten ja alan rakenteellisten piirteiden yhteyksien tutkimiseksi. Aiempien tutkimusten ja koronakyselyiden meta-analyysin pohjalta Comunian ja England (2020) päättelevät, että pandemian vaikutukset vaihtelevat suuresti kulttuurin eri osa-alueilla ja että ne todennäköisesti pahentavat kentällä vallitsevaa eriarvoisuutta (ks. myös Eikhof, 2020). Tutkimusten mukaan kulttuurialoilla on huomattavia sisäänpääsyn ja etenemisen esteitä, jotka liittyvät sukupuoleen, etniseen taustaan ja sosioekonomiseen asemaan. Lisähaasteita nämä alat asettavat myös vammaisille, ikääntyneille ja hoivavelvollisille. (Ks. esim. Brook, O’Brien \& Taylor, 2018; Comunian \& England, 2020; EENCA, s. d.; Eikhof, 2020; Voices of Culture, 2019.)

Suomessa kolme neljästä (76\%) taiteilijasta ilmoitti syys-lokakuussa 2020 toteutetussa taide- ja kulttuuribarometrikyselyssä (1080 vastaajaa) koronapandemian vaikuttaneen heidän taiteelliseen toimintaansa. Näyttelyiden, esitysten, puheiden ja muiden työmahdollisuuksien peruuttamiset ja lykkääntymiset olivat aiheuttaneet heille taloudellisia vaikeuksia ja lisänneet ammatin epävarmuutta. Naisista 13 prosenttia ja miehistä 12 prosenttia oli harkinnut uranvaihtoa. Moni oli koettanut siirtää tekemistään tai sen välitystä digitaaliselle alustalle turvatakseen 
elantoaan. Osa oli saanut erilaisia koronatukia. Toisaalta monet vastaajat olivat tyytyväisiä, kun heillä oli mahdollisuus pysähtyä ja keskittyä taiteeseensa. Naispuoliset taiteilijat olivat kokeneet muutoksia taiteellisessa työssään useammin (79 \%) kuin miespuoliset (69 \%). Naispuolisista vastaajista useat ja miespuolisista muutamat kertoivat lisääntyneestä lastenhoito- ja kotikoulutusvastuusta. (Ruusuvirta, Lahtinen, Rensujeff \& Kurlin Niiniaho, tulossa.)

Opetustyöt ja säännölliset tulot ovat loppuneet. Aikaa omalle taiteelliselle tekemiselle ei ole ollut, koska on käytännössä joutunut olemaan työttömänä kotona hoitamassa pientä lasta ja etäkoululaista. Koronatilanne on vaikuttanut myös syksyn taiteen harrastajaryhmiin, joten tulot opetustoiminnasta ovat tippuneet huomattavasti, enkä ole saanut haettuja apurahoja ainakaan vielä. (Barometrivastaaja: kuvataide ja muotoilu, nainen, 35-49 vuotta.)

Tätä kirjoitettaessa pandemia on kiristänyt uudelleen otettaan monissa Euroopan maissa, ja sen kokonaisvaikutuksia kulttuurialoihin on vaikea ennustaa ${ }^{3}$. Koronakriisin pelätään jättävän kulttuurin kenttään pitkäaikaisen jäljen (ks. esim. Belfiore \& Lee, 2020). Eikhof (2020) arvioi, että pysyäkseen kilpailukykyisinä alan organisaatioiden on säästettävä rahaa kaikkialla, missä se on mahdollista, kuten tehostamalla työtä, leikkaamalla palkkoja ja edellyttämällä joustavia sopimuksia. Epävarmimmissa asemissa olevat työntekijät eivät kestä talouden kiristymistä vaan vaihtavat ammattia, eivätkä he välttämättä palaa, vaikka tilanne muuttuisi. Ala saattaa arvioiden mukaan supistua paitsi volyy- miltään myös diversiteetiltään (Banks, 2020; Eikhof, 2020).

Tutkimusartikkeleissa korostetaan, että koronakriisiä ei tule ymmärtää väliaikaiseksi häiriöksi, kun kulttuurialoilla suunnitellaan politiikkatoimia, vaan on puututtava sen paljastamiin rakenteellisiin ongelmiin. Hätärahoitus ei riitä, jos juuriongelma pysyy. Osa kentän toimijoista ja tutkijoista näkee kriisin mahdollisuutena niin julkiseen politiikkaan kuin alan omiin käytäntöihin ulottuvaan systeemiseen muutokseen. Kansalaispalkka mainitaan useissa tutkimusartikkeleissa yhtenä ratkaisuna parantaa kulttuurityöntekijöiden - ja samalla muiden epätyypillisen työn tekijöiden - epävarmaa tilannetta (ks. esim. Banks, 2020; O'Connor, 2020; Tsioulakis \& FitzGibbon, 2020).

Yksi sitkeistä epäkohdista kulttuurialoilla, kuten laajemminkin työmarkkinoilla, koskee sukupuolten tasa-arvoa. Madgavkar, White, Krishnan, Mahajan ja Azcue (2020) varoittavat, että pandemia taloudellisine seurauksineen taannuttaa merkittävästi sukupuolten tasa-arvoa, jos hallitukset eivät ryhdy välittömästi vastaiskuun. Koronakriisin sukupuolivaikutukset kulttuurialoilla tulisi arvioida, jotta voidaan suunnitella oikeudenmukaisia avustusmuotoja ja elvytyskeinoja. Tasa-arvon edistämiseksi kulttuurialalla työvoiman demografia tulee ylipäätään tehdä näkyväksi, kuten Comunian ja England (2020) toteavat. Avoimen koordinaation työryhmän keskeisiin esityksiin kuuluu, että kulttuurialojen työvoimasta alettaisiin EU-maissa systemaattisesti koota sukupuolen mukaan eriteltyjä tilastoja - niin yllättävältä kuin se kuulostaa, tällaisia ei vielä ole. 


\section{Lähteet}

Abbing, H. (2002). Why are Artists Poor: The Exceptional Economy of the Arts. Amsterdam: Amsterdam University Press.

Alon, T., Doepke, M., Olmstead-Rumsey, J. \& Tertilt, M. (2020). The Impact of COVID-19 on Gender Equality. Covid Economics: Vetted and Real-Time Papers. URL: www.voxeu.org/ article/impact-coronavirus-pandemic-gender-equality (Haettu 30.9.2020)

Banks, M. (2020). The work of culture and C-19. European Journal of Cultural Studies 23 (4), 648654. DOI: $10.1177 / 1367549420924687$

Belfiore, E. \& Lee, H.-K. (2020). Editorial. Cultural Trends, 29 (4), 179-181. DOI: 10.1080/09548963.2020.1835440

Bourdieu, P. (1993). The Field of Cultural Production. Cambridge: Polity Press.

Brook, O., O'Brien, D., \& Taylor, M. (2018). There was no golden age: social mobility into cultural and creative occupations. DOI: 10.31235 /osf. io/7niy3

Caves, R. (2000). The Creative Industries. Contracts between Art and Commerce. Cambridge, MA: Harvard University Press.

Comunian, R. \& England, L. (2020). Creative and cultural work without filters: Covid-19 and exposed precarity in the creative economy. Cultural Trends, 29 (2), 1 12-128.

EENCA (Expert Network on Culture and Audiovisual) (s. d.). Gender gaps in the Cultural and Creative Sectors. Panteia. URL: www.eenca. com/eenca/assets/File/EENCA\%20publications/Final\%20Report\%20-\%20Gender $\% 20$ in $\% 20$ CCS $\% 20$ EAC $\% 20$ with $\% 20$ Additional $\% 20$ sections $\% 20 \mathrm{AV} \% 20$ and $\% 20$ Radio.pdf (Haettu 29.9.2020)

EIGE (European Institute for Gender Equality). (2020). Economic hardship and gender. URL: www.eige.europa.eu/Covid-19-and-gender-equality/economic-hardship-and-gender (Haettu 29.9.2020)

Eikhof, D. R. (2020). COVID-19, inclusion and workforce diversity in the cultural economy: what now, what next? Cultural Trends, 29 (3), 234-250.

Kay, J. B. \& Wood, H. (2020). Cultural commons: Critical responses to COVID-19, part 2. European Journal of Cultural Studies, 23 (6), $1019-$ 1024. DOI: $10.1177 / 1367549420952098$

Madgavkar, A., White, O., Krishnan M., Mahajan, D. \& Azcue, X. (1 5.7.2020). COVID-19 and gender equality: Countering the regressive effects. McKinsey Global Institute. URL: www.mckinsey.com/featured-insights/future-of-work/covid-19-and-gender-equali- ty-countering-the-regressive-effects (Haettu 29.9.2020)

O'Connor, J. (2020, May 8). Art and culture after Covid-19 [blogikirjoitus]. URL: www.wakeinalarm.blog/2020/04/09/art-and-culture-after-covid-19/ (Haettu 30.9.2020)

Ruusuvirta, M., Lahtinen, E. Rensujeff, K. \& Kurlin Niiniaho, A. (tulossa). Taiteen ja kulttuurin barometri 2020 (työnimi). Helsinki: Kulttuuripolitiikan tutkimuskeskus Cupore.

Tsioulakis, I. \& FitzGibbon, A. (9.4.2020). Performing artists in the age of COVID-19: $A$ moment of urgent action and potential change [blogikirjoitus]. URL: www.qpol.qub.ac.uk/ performing-artists-in-the-age-of-Covid-19/ (Haettu 29.9.2020)

United Nations (2020). Policy Brief: The Impact of COVID-19 on Women. URL: www.unwomen. org/-/media/headquarters/attachments / sections/library/publications/2020/policybrief-the-impact-of-covid-19-on-women-en. pdf?la=en\&vs=1406 (Haettu 29.9.2020)

Voices of Culture (2019). Gender Equality: Gender Balance in the Cultural and Creative Sectors. URL: www.voicesofculture.eu/ wp-content/uploads/2020/02/VoC-Brainstorming-Report-Gender-Balance-in-the-Cultural-and-Creative-Sectors.pdf (Haettu 30.9.2020)

World Bank Group (2020). Policy Note: Gender dimensions of the COVID-19 pandemic. URL: www.documents 1.worldbank.org/curated/ en/618731587147227244/pdf/Gender-Dimensions-of-the-COVID-19-Pandemic. pdf (Haettu 30.9.2020)

\section{Loppuviitteet}

1. Artikkelissa nojataan binaariseen jakoon avoimen koordinaation työryhmän toimeksiannon mukaisesti.

2. Käytämme jatkossa lyhyempää ilmaisua "kulttuurialat". Eurooppalaisessa keskustelussa vastine on "kulttuuriset ja luovat toimialat" (cultural and creative industries, CCIs).

3. Suomen tilanteesta ks. Jakonen, Luonila, Renko ja Kanerva tässä numerossa. 